Article

\title{
Citrus Extract Improves the Absorption and Utilization of Nitrogen and Gut Health of Piglets
}

\author{
Yiyan Cui ${ }^{1,2,3,4,5}$, Zhimei Tian ${ }^{1,2,3,4,5}$, Gang Wang 1,2,3,4,5, Xianyong Ma $1,2,3,4,5, *$ and \\ Weidong Chen $1,2,3,4,5, *$ \\ 1 Institute of Animal Science, Guangdong Academy of Agricultural Sciences, Guangzhou 510640, China; \\ cuiyiyan@gdaas.cn (Y.C.); tianzhimei@gdaas.cn (Z.T.); wanggang@gdaas.cn (G.W.) \\ 2 State Key Laboratory of Livestock and Poultry Breeding, Guangzhou 510640, China \\ 3 Key Laboratory of Animal Nutrition and Feed Science in South China, Ministry of Agriculture, \\ Guangzhou 510640, China \\ 4 Guangdong Key Laboratory of Animal Breeding and Nutrition, Guangzhou 510640, China \\ 5 Guangdong Engineering Technology Research Center of Animal Meat Quality and Safety Control and \\ Evaluation, Guangzhou 510640, China \\ * Correspondence: maxianyong@gdaas.cn (X.M.); chenweidong@gdaas.cn (W.C.); \\ Tel.: +86-020-6136-8896 (X.M.); +86-020-8757-7891 (W.C.)
}

Received: 14 November 2019; Accepted: 8 January 2020; Published: 10 January 2020

check for updates

Simple Summary: Weaning can cause weaning stress and reduce the growth performance of piglets. Citrus extract has strong anti-oxidant and anti-inflammatory effects which can improve animal health. The aim of this study was to evaluate the efficacy of citrus extract as a substitute for antibiotics in piglet diets. The results of this study indicate that citrus extract increased the concentrations of plasma essential amino acids, improved intestinal morphology and digestive enzymes activity.

\begin{abstract}
The purpose of this study was to investigate the effects of citrus extract (CE) on plasma free amino acids, intestinal morphology and enzymes activity, fecal nitrogen and phosphorus emissions in piglets. The experiment was performed on 144 weaned piglets (Duroc $\times$ Landrace $\times$ Large White) divided into three groups. Control (CON), fed a basic diet; Antibiotic (ANTI), fed a basic diet supplemented with $75 \mathrm{~g} / \mathrm{t}$ chlortetracycline; Citrus extract (CE), fed a basic diet supplemented with $300 \mathrm{~mL} / \mathrm{t}$ CE. The albumin content of the CE group was significantly higher than the CON group. Compared with the CON and ANTI groups, the CE group had increased concentrations of plasma total essential amino acids and threonine. Compared with the CON group, CE increased the $\alpha$-aminoadipic acid concentration, while compared with ANTI group, it increased the 3-methylhistidine concentration. Compared with the CON group, the crypt depth of duodenum, jejunum and ileum decreased, and the ratio of villus height to crypt depth of ileum increased in the ANTI and CE groups. CE increased the activity of alkaline phosphatase and lipase in duodenum, and the activity of alkaline phosphatase and trypsin in jejunum. In brief, CE improved the absorption and utilization of nitrogen, intestinal morphology and digestive enzymes activity.
\end{abstract}

Keywords: citrus extract; piglet; plasma free amino acids; intestinal morphology; intestinal enzymes; ammonia nitrogen; nitrogen; phosphorus

\section{Introduction}

Weaning changes the physiology of animals and can lead to intestinal dysfunction [1]. While diarrhea is not the only symptom of intestinal dysfunction after weaning, digestive functions are the most impacted by weaning. Antibiotics are commonly used to treat these conditions, to prevent diarrhea, promote growth, and improve intestinal digestion and absorption. However, the overuse of 
antibiotics can result in drug-resistant bacteria and environmental pollution. In addition, animal manure emits a large amount of noxious gas, nitrogen $(\mathrm{N})$, and phosphorus $(\mathrm{P})$, which can have adverse effects on animal and human health and may be increased by intestinal distress. Finding an alternative to antibiotics that reduces both antibiotic use and $\mathrm{N}$ emissions, improves animal growth, benefits farms economically, and reduces environmental pollution would benefit multiple sectors of society.

In general, nutrient excretion can be reduced by avoiding excessive feeding of specific nutrients or enhancing nutrient use by the animal through nutrient operations [2]. Citrus flavonoids are reported to be the most biologically active compounds on Earth [3]. Hesperidin, for example, can prevent intestinal inflammation in mice [4]. Citrus extract (CE) has various biological functions, including anti-cancer [5], anti-bacterial [6,7], anti-oxidant [7,8], and anti-inflammatory [9,10]. Its strong anti-oxidant and anti-inflammatory effects are especially valuable in improving animal health $[9,11]$. Animal experiments have shown that orange peel extract improved immune response and disease resistance of broilers without affecting their average daily gain (ADG), average daily feed intake (ADFI), and feed conversion rate [12]. Citrus flavonoids may prolong the shelf life of eggs, appear to possess anti-inflammatory properties and could improve the yolk color without having any side effects on the performance or egg quality traits [9]. Citrus purified bioactive compounds have also been shown to improve the anti-oxidant capacity of plasma and meat in sheep [13]. Our own studies have shown that CE improved the anti-oxidant capacity and immune function of piglets [14].

Immunization stimulates a change in the utilization of amino acids (AA), which leads to reduced productivity in pigs by repurposing AA away from protein retention for use in immune responses [15]. Plasma-free amino acids (PFAA) are a primarily source of AA used for muscle protein biosynthesis, a key indicator of protein turnover in the body [16]. We hypothesized that CE benefits the intestinal ammonia nitrogen (AN) content as well as the fecal $\mathrm{N}$ and $\mathrm{P}$ emissions in piglets by improving protein (AA) metabolism and intestinal health. Therefore, this study evaluated the effects of CE supplementation on plasma biochemistry, PFAA, intestinal morphology and digestive enzymes activity, AN content, and fecal $\mathrm{N}$ and $\mathrm{P}$ emissions in piglets.

\section{Materials and Methods}

This study was carried out in accordance with the Guiding Suggestions About Treating Experimental Animals Amicably of the Science and Technology Ministry of China (2006, Document no. 398, China). Animal procedures experiments were approved by the Animal Care and Use Committee of Guangdong Academy of Agricultural Sciences (authorization number GAASIAS-2017-11-17).

\subsection{Materials}

Chlortetracycline was purchased from Guangdong Newland Feed Science \& Technology Co., Ltd. CE was provided by Guangdong Runsen Environmental Technology Development Co., Ltd. The primary active ingredients of CE are the total flavonoids (20.77\%), vitamin C (3.04\%), citric acid $(2.89 \%)$, and vitamin E $(2.38 \%)$.

\subsection{Experimental Design, Animals and Diets}

A total of 144 crossbred piglets (Duroc $\times$ Landrace $\times$ Large White) weaned at 28 days of age $(8.39 \pm 0.10 \mathrm{~kg})$ were used. Piglets were assigned to one of 3 dietary treatments. Each treatment comprised 6 pens, with 8 pigs ( 4 barrows and 4 gilts) in each. Control pigs (CON) were fed a corn-soybean meal basal diet, antibiotic pigs (ANTI) were fed the basal diet supplemented with $75 \mathrm{~g} / \mathrm{t}$ chlortetracycline, the others were fed the basal diet supplemented with $300 \mathrm{~mL} / \mathrm{t}$ citrus extract (CE). All experimental diets were formulated to meet the nutrient requirements suggested by the NRC (2012; Table 1). All piglets had ad libitum access to feed and water throughout the 28-day experimental period. 
Table 1. Composition and nutrient levels of basal diets (air-dry basis).

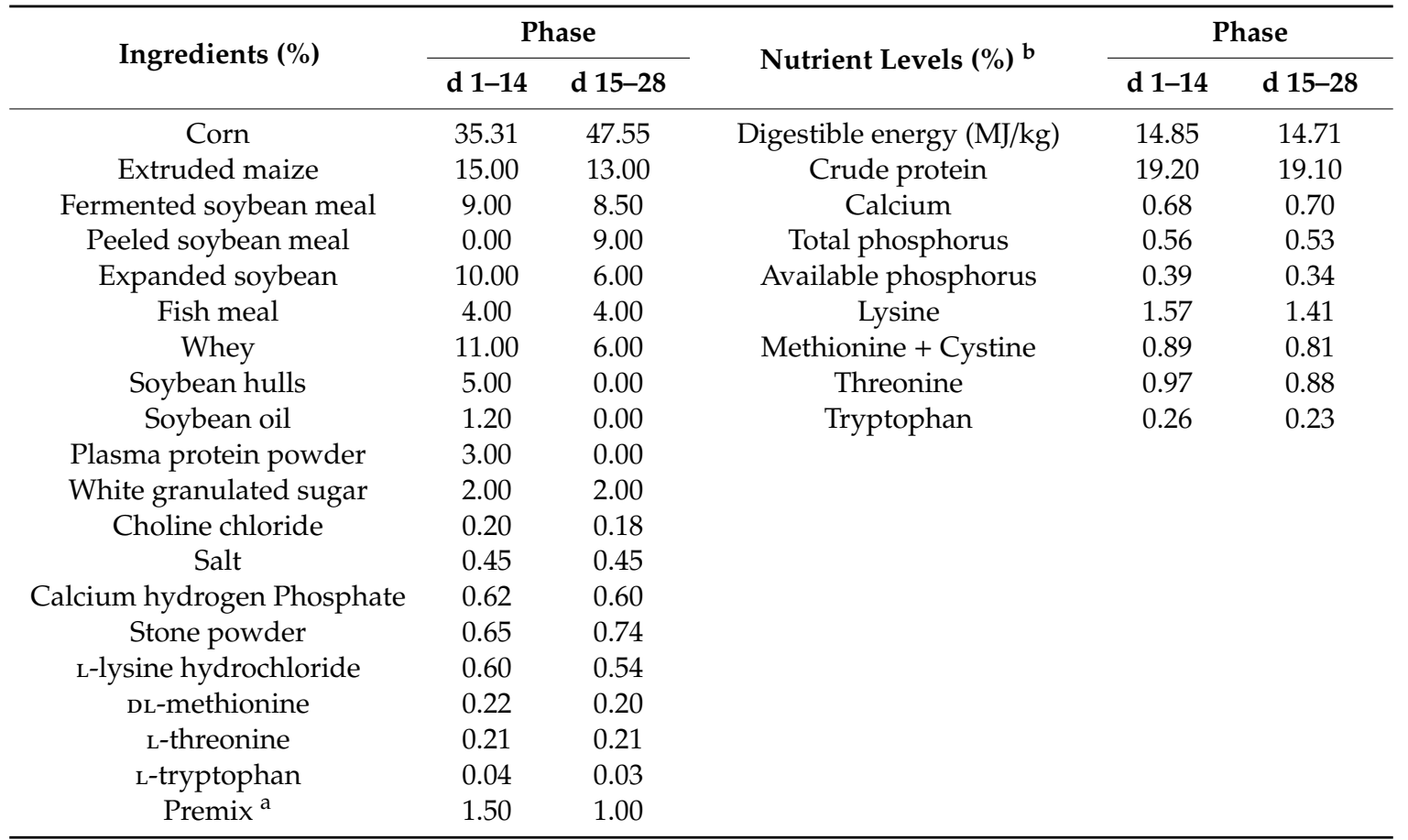

a 1 to $14 \mathrm{~d}$ premix for each $\mathrm{kg}$ of diet: VA 12,400 IU, VD $2800 \mathrm{IU}, \mathrm{VE} 30 \mathrm{IU}, \mathrm{VK} 5 \mathrm{mg}, \mathrm{VB}_{12} 40 \mu \mathrm{g}, \mathrm{VB}_{1} 3 \mathrm{mg}$, $\mathrm{VB}_{2} 10 \mathrm{mg}$, nicotinic acid $40 \mathrm{mg}$, D-pantothenic acid $15 \mathrm{mg}$, folic acid $1 \mathrm{mg}, \mathrm{VB}_{6} 8 \mathrm{mg}$, biotin $0.08 \mathrm{mg}, \mathrm{FeSO}_{4} \cdot \mathrm{H}_{2} \mathrm{O}$ $120 \mathrm{mg}, \mathrm{CuSO}_{4} \cdot 5 \mathrm{H}_{2} \mathrm{O} 16 \mathrm{mg}, \mathrm{MnSO}_{4} \cdot \mathrm{H}_{2} \mathrm{O} 70 \mathrm{mg}, \mathrm{ZnSO}_{4} \cdot \mathrm{H}_{2} \mathrm{O} 120 \mathrm{mg}, \mathrm{CaI}_{2} \mathrm{O}_{6} 0.7 \mathrm{mg}, \mathrm{Na}_{2} \mathrm{SeO}_{3} 0.48 \mathrm{mg} .15$ to $28 \mathrm{~d}$ premix for each $\mathrm{kg}$ of diet: VA $12,400 \mathrm{IU}, \mathrm{VD}_{3} 2800 \mathrm{IU}, \mathrm{VE} 30 \mathrm{IU}, \mathrm{VK} 5 \mathrm{mg}, \mathrm{VB}_{12} 40 \mu \mathrm{g}, \mathrm{VB}_{1} 3 \mathrm{mg}, \mathrm{VB}_{2}, 10 \mathrm{mg}$, nicotinic acid $40 \mathrm{mg}$, D-pantothenic acid $15 \mathrm{mg}$, folic acid $1 \mathrm{mg}, \mathrm{VB}_{6} 8 \mathrm{mg}$, biotin $0.08 \mathrm{mg}, \mathrm{FeSO}_{4} \cdot \mathrm{H}_{2} \mathrm{O} 90 \mathrm{mg}$, $\mathrm{CuSO}_{4} \cdot 5 \mathrm{H}_{2} \mathrm{O} 12 \mathrm{mg}, \mathrm{MnSO}_{4} \cdot \mathrm{H}_{2} \mathrm{O} 53 \mathrm{mg}, \mathrm{ZnSO}_{4} \cdot \mathrm{H}_{2} \mathrm{O} 90 \mathrm{mg}, \mathrm{CaI}_{2} \mathrm{O}_{6} 0.53 \mathrm{mg}, \mathrm{Na}_{2} \mathrm{SeO}_{3} 0.36 \mathrm{mg} .{ }^{\mathrm{b}}$ Calculated value. The values are expressed as percentage (\%), except for digestible energy.

\subsection{Sample Collection and Slaughter Procedure}

During the experiment, the piglets body weight (BW) were measured at $0 \mathrm{~d}$ (start) and $28 \mathrm{~d}$ (finish) of the experiment to calculate the average daily gain (ADG). The feed consumption was measured every day to calculate the average daily feed intake (ADFI) and feed to gain ratio (F/G). Fresh fecal grab samples were collected in the morning during the last week (experimental $\mathrm{d}$ 21-28) and pooled by pen and stored at $-20^{\circ} \mathrm{C}$ for $\mathrm{N}$ and $\mathrm{P}$ emissions analysis. Each piglet was weighed at the end of the experiment, the two pigs closest to the average weight of treatments were selected from each replicate pen for slaughter. Approximately $12 \mathrm{~h}$ before slaughter, feed was withheld, but water remained available. Blood samples (sodium-EDTA) were allowed to rest at room temperature for a few minutes and centrifuged at $1800 \times \mathrm{g}$ at $4{ }^{\circ} \mathrm{C}$ for $10 \mathrm{~min}$ to extract the plasma which was then frozen at $-80^{\circ} \mathrm{C}$ until analysis. Animals were maintained under general anesthesia and intravenously euthanized via a jugular injection of $4 \%$ sodium pentobarbital solution $(40 \mathrm{mg} / \mathrm{kg} \mathrm{BW})$. For intestinal morphology examination, samples of the duodenum (middle), jejunum (a segment of the small intestine 2-3 m proximal to the duodenum), and ileum (a segment of the small intestine $1 \mathrm{~m}$ proximal to the ileocecal junction) were dissected out and immediately put into $4 \%$ paraformaldehyde. A section of duodenum and jejunum were washed with phosphate buffer saline, and immersed quickly in liquid nitrogen, before stored at $-80^{\circ} \mathrm{C}$ for digestive enzymes activity analysis. The digesta in the jejunum and ileum were collected and immediately immersed in liquid nitrogen and stored at $-80^{\circ} \mathrm{C}$ for AN analysis.

\subsection{Plasma Biochemistry}

Plasma urea nitrogen (PUN, C013-2-1, urease method), albumin (A028-1-1, colorimetry), and total protein (TP, A045-2-1, coomassie brilliant blue method) were measured using assay kits according to the manufacturer's instructions (Nanjing Jiancheng Bioengineering Institute, Nanjing, China). The plate 
was read by a multi-functional enzyme labeling instrument (Spectra Max M5, Molecular Devices, San Jose, CA, USA) at $640 \mathrm{~nm}$ (PUN), $628 \mathrm{~nm}$ (albumin), and $595 \mathrm{~nm}$ (TP). There were 3 duplicates for each plasma sample, and 12 replicates in each group.

\subsection{Urea, NH3, and PFAA}

The amounts of urea, $\mathrm{NH}_{3}$, and PFAA were determined using a post-column derivatization of ninhydrin. Exactly $400 \mu \mathrm{L}$ plasma was absorbed and $1.2 \mathrm{~mL} \mathrm{10 \%} \mathrm{sulfosalicylic} \mathrm{acid} \mathrm{was} \mathrm{added} \mathrm{and}$ mixed fully. Then, it was centrifuged at $12,000 \times g$ for $15 \mathrm{~min}$ at $4{ }^{\circ} \mathrm{C}$. The supernatants were filtered with $0.22 \mu \mathrm{m}$ filters for testing. The urea, $\mathrm{NH}_{3}$, and PFAA concentrations were measured with an automatic amino acid detector equipped with sodium ion exchange column (L-8900, HITACHI, Tokyo, Japan). There were 3 duplicates for each plasma sample, and 12 replicates in each group.

\subsection{Intestinal Morphology}

The procedure for determining of intestinal morphology was as follows. The intestinal samples were dehydrated, embedded, sectioned, hematoxylin-eosin stained, observed under microscope, and scanned. The Pannoramic Viewer version 1.15.3 software (3DHISTECH, Budapest, Hungary) was used to measure the villus height (VH), crypt depth (CD), and villus height to crypt depth ratio (VCR), and 8 replicates of complete and upright villus from each histological section were selected for measurement. Villus height was defined as the distance from villus base to tip, and crypt depth as the distance from villus base to lamina muscularis mucosae. There were 12 histological sections in each group.

\subsection{Intestinal Digestive Enzymes Activity}

The activity of digestive enzymes was measured after homogenization of duodenum and jejunum tissue in $0.9 \%$ saline at $1: 9(\mathrm{m:v})$, at $1500 \mathrm{r} / \mathrm{min}$ for $2 \mathrm{~min}$, followed by centrifugation at $1800 \times g$ and $4{ }^{\circ} \mathrm{C}$ for $15 \mathrm{~min}$. The supernatant was collected and then the activities of $\alpha$-amylase (C016-1-1, starch-iodine colorimetry), lipase (A054-1-1, colorimetry), sucrose (A082-2-1, colorimetry), maltase (A082-3-1, colorimetry), pepsin (A080-1-1, colorimetry), trypsin (A080-2-2, ultraviolet colorimetry), and alkaline phosphatase (AKP, A059-1-1, colorimetry) were determined according to kit instructions (Nanjing Jiancheng Bioengineering Institute, Nanjing, China). The plate was read by a multi-functional enzyme labeling instrument (Spectra Max M5, Molecular Devices, San Jose, CA, USA) at $660 \mathrm{~nm}$ ( $\alpha$-amylase and pepsin), $420 \mathrm{~nm}$ (lipase), $505 \mathrm{~nm}$ (sucrose and maltase), $253 \mathrm{~nm}$ (trypsin) and $520 \mathrm{~nm}$ (AKP). There were 3 duplicates for each homogenate sample, and 12 replicates in each group.

\subsection{Ammonia Nitrogen}

AN content in intestinal digesta was determined by indigo phenol blue-spectrophotometry, according to $\mathrm{Pu}$ et al. [17]. The intestinal content was mixed with $0.2 \mathrm{~mol} / \mathrm{L}$ hydrochloric acid at $1: 9$ (m:v) and stored at $-20^{\circ} \mathrm{C}$. Before measuring, the mixture was thawed, then centrifuged at $10,000 \times g$ for $10 \mathrm{~min}$ at $4^{\circ} \mathrm{C}$, and the supernatant was taken for colorimetric analysis. The optimum conditions for the determination were $25 \mathrm{mg} / \mathrm{L}$ catalyst, water-soluble coloring at $40{ }^{\circ} \mathrm{C}$ for $20 \mathrm{~min}$. The plate was read by a multi-functional enzyme labeling instrument (Spectra Max M5, Molecular Devices, San Jose, CA, USA) at $640 \mathrm{~nm}$. There were 3 duplicates for each intestinal digesta sample, and 12 replicates in each group.

\subsection{Fecal $N$ and $P$}

For $\mathrm{N}$ and $\mathrm{P}$ analysis, fecal samples were oven-dried at $65^{\circ} \mathrm{C}$ for $72 \mathrm{~h}$, then, those samples were crushed and sieved through a 100 mesh sieve. Fecal $\mathrm{N}$ was measured by transferring $0.2 \mathrm{~g}$ of each fecal sample into a digestive tube. Catalyst and concentrated sulfuric acid were added and digestion proceeded at $420^{\circ} \mathrm{C}$ for $2 \mathrm{~h}$, and then $\mathrm{N}$ was determined using an automatic nitrogen analyzer (8400, 
FOSS, Hillerod, Denmark). Fecal P was determined with the phosphorus vanadium molybdate yellow colorimetric method. First, $1.0 \mathrm{~g}$ sample was carbonized until smokeless, before being burned in a muffle oven at $550{ }^{\circ} \mathrm{C}$ for $6 \mathrm{~h}$. After cooling, $10 \mathrm{~mL} 6 \mathrm{~mol} / \mathrm{L}$ hydrochloric acid and a few drops of nitric acid were added, and the solution was boiled for $10 \mathrm{~min}$, then made up to a volume of $100 \mathrm{~mL}$ with pure water. Finally, $1 \mathrm{~mL}$ of the solution was taken out for colorimetric analysis. The plate was read by a multi-functional enzyme labeling instrument (Spectra Max M5, Molecular Devices, San Jose, CA, USA) at $420 \mathrm{~nm}$. There were 3 duplicates for each fecal sample, and 6 replicates in each group.

\subsection{Statistical Analyses}

Statistical analysis was computed using the Statistical Package for Social Sciences (SPSS) software, version 19.0. The results were analyzed using Duncan's multiple range tests and one-way analysis of variance (ANOVA). Results are expressed as mean values and SEM, $p \leq 0.05$ was considered significant, and $0.05<p \leq 0.10$ indicated a trend.

\section{Results}

\subsection{Animal Performance}

Data on animal performance are reported in Table 2. Dietary treatments had no effect on initial BW, final BW, ADG, ADFI, or F/G ( $p>0.05)$.

Table 2. Effects of citrus extract diets, on initial body weight, final body weight, average daily gain (ADG), average daily feed intake (ADFI) and feed to gain ratio $(\mathrm{F} / \mathrm{G})$ of piglets.

\begin{tabular}{cccccc}
\hline Items & CON $^{\mathbf{1}}$ & ANTI $^{\mathbf{2}}$ & CE $^{3}$ & SEM $^{4}$ & $p$-Value \\
\hline Initial BW (kg) & 8.4 & 8.5 & 8.3 & 0.08 & 0.301 \\
Final BW (kg) & 16.4 & 17.4 & 17.0 & 0.34 & 0.144 \\
ADG (g) & 284.9 & 316.6 & 313.0 & 14.83 & 0.332 \\
ADFI (g) & 597 & 620 & 605 & 17.16 & 0.652 \\
F/G & 2.1 & 2.0 & 1.9 & 0.09 & 0.407
\end{tabular}

${ }^{1}$ CON: basal diet; ${ }^{2}$ ANTI: CON $+75 \mathrm{~g} / \mathrm{t}$ chlortetracycline; ${ }^{3} \mathrm{CE}: \mathrm{CON}+300 \mathrm{~mL} / \mathrm{t}$ citrus extract; ${ }^{4} \mathrm{SEM}$ means standard error of the mean.

\subsection{Plasma Biochemical Indicators}

As shown in Table 3, compared with the CON group, the albumin content of the CE group was significantly increased by $18.8 \%(p=0.011)$. The ratio of albumin to TP increased significantly $(p=0.015)$ in the CE and ANTI groups. There were no significant differences in plasma urea, $\mathrm{NH}_{3}$, PUN, or TP concentration among the three treatments $(p>0.05)$.

Table 3. Effects of citrus extract diets, on plasma urea, $\mathrm{NH}_{3}$, plasma urea nitrogen (PUN), albumin, total protein (TP) and albumin/TP of piglets.

\begin{tabular}{cccccc}
\hline Items & CON $^{\mathbf{1}}$ & ANTI $^{2}$ & CE $^{3}$ & SEM $^{4}$ & $p$-Value \\
\hline Urea $(\mathrm{ng} / \mu \mathrm{L})$ & 137.2 & 136.9 & 158.5 & 10.89 & 0.300 \\
$\mathrm{NH}_{3}(\mathrm{ng} / \mu \mathrm{L})$ & 2.0 & 2.7 & 1.7 & 0.58 & 0.571 \\
PUN $(\mathrm{mmol} / \mathrm{L})$ & 4.9 & 5.0 & 5.5 & 1.01 & 0.274 \\
Albumin $(\mathrm{g} / \mathrm{L})$ & $28.7^{\mathrm{b}}$ & $31.3^{\mathrm{a}, \mathrm{b}}$ & $34.1^{\mathrm{a}}$ & 3.87 & 0.011 \\
$\mathrm{TP}(\mathrm{g} / \mathrm{L})$ & 53.8 & $51.6^{\mathrm{a}}$ & 53.9 & 2.89 & 0.113 \\
Albumin $/ \mathrm{TP}$ & $0.5^{\mathrm{b}}$ & $0.6^{\mathrm{a}}$ & $0.6^{\mathrm{a}}$ & 0.08 & 0.015 \\
\hline
\end{tabular}

a,b Means in the same row with different superscripts differ $(p<0.05) .{ }^{1}$ CON: basal diet; ${ }^{2}$ ANTI: CON $+75 \mathrm{~g} / \mathrm{t}$ chlortetracycline; ${ }^{3} \mathrm{CE}: \mathrm{CON}+300 \mathrm{~mL} / \mathrm{t}$ citrus extract; ${ }^{4} \mathrm{SEM}$ means standard error of the mean. 


\subsection{PFAA}

The PFAA were determined and are described in Table 4. Compared with CON and ANTI groups, the CE group had higher concentrations of plasma total essential amino acids (EAA) $(p=0.003)$, threonine $(p<0.001)$, leucine $(p=0.054)$, histidine $(p=0.066)$, arginine $(p=0.094)$, valine $(p=0.094)$, and citrulline $(p=0.081)$. Compared with the CON group, CE increased $\alpha$-amino adipic acid $(p=0.035)$ content, while compared with the ANTI group, CE increased 3-methylhistidine $(p=0.020)$ content.

Table 4. Effects of citrus extract diets on plasma free amino acids (PFAA) of piglets (ng/ $\mu \mathrm{L})$.

\begin{tabular}{|c|c|c|c|c|c|}
\hline Items & $\mathrm{CON}^{1}$ & ANTI $^{2}$ & $C E^{3}$ & SEM $^{4}$ & $p$-Value \\
\hline \multicolumn{6}{|l|}{ EAA $^{5}$} \\
\hline Isoleucine & 7.7 & 7.8 & 9.0 & 0.58 & 0.228 \\
\hline Leucine & 13.6 & 13.2 & 15.7 & 0.73 & 0.054 \\
\hline Methionine & 5.3 & 4.9 & 4.8 & 0.36 & 0.619 \\
\hline Lysine & 17.6 & 16.8 & 20.4 & 1.69 & 0.322 \\
\hline Histidine & 5.1 & 5.2 & 6.7 & 0.49 & 0.066 \\
\hline Arginine & 11.8 & 10.5 & 14.0 & 1.56 & 0.094 \\
\hline Valine & 13.2 & 11.2 & 15.0 & 1.11 & 0.094 \\
\hline Phenylalanine & 9.8 & 9.5 & 11.1 & 0.62 & 0.190 \\
\hline Threonine & $12.8^{\mathrm{b}}$ & $15.2^{b}$ & $24.2^{\mathrm{a}}$ & 5.54 & $<0.001$ \\
\hline \multicolumn{6}{|l|}{ NEAA $^{6}$} \\
\hline Aspartate & 2.2 & 1.7 & 2.4 & 0.21 & 0.113 \\
\hline Serine & 12.9 & 13.5 & 11.7 & 0.57 & 0.109 \\
\hline Glutamate & 26.2 & 26.8 & 27.5 & 1.97 & 0.898 \\
\hline Glycine & 59.0 & 68.7 & 57.5 & 4.77 & 0.235 \\
\hline Alanine & 37.8 & 34.6 & 35.8 & 6.50 & 0.941 \\
\hline Cystine & 5.2 & 5.3 & 6.3 & 0.56 & 0.337 \\
\hline Tyrosine & 7.4 & 7.5 & 8.6 & 0.50 & 0.201 \\
\hline Proline & 19.8 & 19.6 & 19.6 & 1.38 & 0.992 \\
\hline Hydroxy proline & 15.1 & 15.6 & 12.5 & 1.04 & 0.110 \\
\hline$\beta$-alanine & 2.8 & 2.9 & 2.6 & 0.25 & 0.740 \\
\hline Ornithine & 6.1 & 6.5 & 7.3 & 0.47 & 0.207 \\
\hline Citrulline & 6.3 & 6.0 & 8.3 & 0.68 & 0.081 \\
\hline Cystathionine & 4.3 & 4.2 & 4.1 & 0.35 & 0.940 \\
\hline Phosphoserine & 1.3 & 1.3 & 1.3 & 0.26 & 0.994 \\
\hline Taurine & 17.6 & 19.1 & 21.0 & 0.51 & 0.342 \\
\hline$\alpha$-amino adipic acid & $6.8^{b}$ & $7.2^{\mathrm{a}, \mathrm{b}}$ & $8.9^{a}$ & 0.55 & 0.035 \\
\hline$\alpha$-amino-n-butyric acid & 1.5 & 1.9 & 2.1 & 0.19 & 0.101 \\
\hline 1-methylhistidine & 2.1 & 2.6 & 2.2 & 0.40 & 0.682 \\
\hline 3-methylhistidine & $1.8^{\mathrm{a}, \mathrm{b}}$ & $1.2^{b}$ & $2.9^{\mathrm{a}}$ & 0.29 & 0.020 \\
\hline$\Sigma \mathrm{EAA}^{7}$ & $96.3^{b}$ & $94.2^{b}$ & $120.6^{\mathrm{a}}$ & 5.34 & 0.003 \\
\hline$\Sigma \mathrm{NEAA}^{8}$ & 231.7 & 240.8 & 235.0 & 13.08 & 0.888 \\
\hline$\Sigma \mathrm{AA}^{9}$ & 328.1 & 335.0 & 355.7 & 15.83 & 0.459 \\
\hline
\end{tabular}

a,b Means in the same row with different superscripts differ $(p<0.05) .{ }^{1} \mathrm{CON}$ : basal diet; ${ }^{2}$ ANTI: CON $+75 \mathrm{~g} / \mathrm{t}$ chlortetracycline; ${ }^{3} \mathrm{CE}: \mathrm{CON}+300 \mathrm{~mL} / \mathrm{t}$ citrus extract; ${ }^{4} \mathrm{SEM}$ means standard error of the mean; ${ }^{5} \mathrm{EAA}:$ essential amino acids; ${ }^{6}$ NEAA: non-essential amino acids ${ }^{7} \Sigma$ EAA $=$ Total essential amino acids; ${ }^{8} \Sigma$ NEAA $=$ Total non-essential amino acids ${ }^{9} \Sigma \mathrm{AA}=$ Total amino acids.

\subsection{Intestinal Morphology}

The effect of CE on piglets' intestinal morphology was assessed and is presented in Table 5. Compared with the CON group, the CD of duodenum $(p=0.004)$, jejunum $(p=0.013)$ and ileum $(p<0.001)$ decreased significantly, and the VCR of the duodenum $(p=0.057)$ and ileum $(p<0.001)$ increased in ANTI and CE groups. There were no significant differences in VH on the duodenum, jejunum or ileum among the three groups $(p>0.05)$. 
Table 5. Effects of citrus extract diets, on villus height (VH) and crypt depth (CD) of duodenum, jejunum, and ileum in piglets.

\begin{tabular}{|c|c|c|c|c|c|}
\hline Items & $\mathrm{CON}^{1}$ & ANTI $^{2}$ & $\mathrm{CE}^{3}$ & SEM $^{4}$ & $p$-Value \\
\hline \multicolumn{6}{|c|}{ Villus height $(\mu \mathrm{m})$} \\
\hline Duodenum & 370.3 & 334.5 & 415.4 & 56.76 & 0.093 \\
\hline Jejunum & 377.0 & 396.4 & 369.3 & 52.10 & 0.585 \\
\hline Ileum & 308.0 & 370.6 & 347.8 & 65.87 & 0.189 \\
\hline \multicolumn{6}{|c|}{ Crypt depth $(\mu \mathrm{m})$} \\
\hline Duodenum & $447.4^{\mathrm{a}}$ & $375.1^{\mathrm{b}}$ & $391.9^{a, b}$ & 40.62 & 0.004 \\
\hline Jejunum & $293.4^{\mathrm{a}}$ & $243.7^{b}$ & $232.5^{b}$ & 37.05 & 0.013 \\
\hline Ileum & $267.8^{a}$ & $189.8^{\mathrm{b}}$ & $191.1^{b}$ & 24.71 & $<0.001$ \\
\hline \multicolumn{6}{|c|}{ Villus height/crypt depth } \\
\hline Duodenum & 0.9 & 1.0 & 1.1 & 0.15 & 0.057 \\
\hline Jejunum & 1.5 & 1.7 & 1.7 & 0.33 & 0.389 \\
\hline Ileum & $1.2^{b}$ & $2.1^{\mathrm{a}}$ & $2.0^{\mathrm{a}}$ & 0.37 & $<0.001$ \\
\hline
\end{tabular}

a,b Means in the same row with different superscripts differ $(p<0.05) .{ }^{1}$ CON: basal diet; ${ }^{2}$ ANTI: CON $+75 \mathrm{~g} / \mathrm{t}$ chlortetracycline; ${ }^{3} \mathrm{CE}: \mathrm{CON}+300 \mathrm{~mL} / \mathrm{t}$ citrus extract; ${ }^{4}$ SEM means standard error of the mean.

\subsection{Digestive Enzymes Activity}

As shown in Table 6, compared with the CON group, the activity of AKP in duodenum was significantly increased in the CE and ANTI groups $(p=0.004)$. Duodenal lipase activity in the CE group was significantly higher than that in the CON and ANTI groups $(p=0.021)$. ANTI and CE tended to increase the activity of duodenal trypsin $(p=0.051)$. CE significantly increased jejunum AKP activity compared with the CON group $(p=0.041)$ and tended to increase the activity of lipase $(p=0.052)$. ANTI and CE groups significantly increased jejunum trypsin activity $(p=0.007)$.

Table 6. Effects of citrus extract diets, on alkaline phosphatase (AKP), lipase, $\alpha$-amylase, sucrose, maltase, pepsin and trypsin of duodenum and jejunum in piglets (U/mgprot).

\begin{tabular}{cccccc}
\hline Items & CON $^{\mathbf{1}}$ & ANTI $^{\mathbf{2}}$ & CE $^{\mathbf{3}}$ & SEM $^{\mathbf{4}}$ & $p$-Value \\
\hline Duodenum & & & & & \\
AKP & $2119.7^{\mathrm{b}}$ & $2668.8^{\mathrm{a}}$ & $2983.2^{\mathrm{a}}$ & 141.33 & 0.004 \\
Lipase (U/gprot) & $162.5^{\mathrm{b}}$ & $170.9^{\mathrm{b}}$ & $198.1^{\mathrm{a}}$ & 7.96 & 0.021 \\
$\alpha$-amylase & $0.3^{\mathrm{a}}$ & 0.3 & 0.3 & 0.01 & 0.202 \\
Sucrase & 72.6 & 75.3 & 79.1 & 6.48 & 0.815 \\
Maltase & 193.7 & 156.8 & 197.1 & 41.78 & 0.774 \\
Pepsin & 0.9 & 1.1 & 1.0 & 0.15 & 0.730 \\
Trypsin & 25.0 & 43.9 & 40.0 & 4.96 & 0.051 \\
\hline Jejunum & & & & & \\
AKP & $1973.2^{\mathrm{b}}$ & $2207.2^{\mathrm{a}, \mathrm{b}}$ & $2703.7^{\mathrm{a}}$ & 173.41 & 0.041 \\
Lipase (U/gprot) & 146.8 & 159.0 & 178.9 & 7.73 & 0.052 \\
$\alpha$-amylase & 0.2 & 0.3 & 0.3 & 0.01 & 0.188 \\
Sucrase & 61.1 & 66.3 & 69.8 & 6.70 & 0.677 \\
Maltase & 59.6 & 47.0 & 60.7 & 15.60 & 0.806 \\
Pepsin & 0.4 & 0.8 & 0.4 & 0.16 & 0.250 \\
Trypsin & $7.1^{\mathrm{b}}$ & $43.8^{\mathrm{a}}$ & $41.0^{\mathrm{a}}$ & 7.13 & 0.007 \\
\hline
\end{tabular}

a,b Means in the same row with different superscripts differ $(p<0.05) .{ }^{1}$ CON: basal diet; ${ }^{2}$ ANTI: CON $+75 \mathrm{~g} / \mathrm{t}$ chlortetracycline; ${ }^{3} \mathrm{CE}: \mathrm{CON}+300 \mathrm{~mL} / \mathrm{t}$ citrus extract; ${ }^{4} \mathrm{SEM}$ means standard error of the mean.

\subsection{AN in Intestinal Digesta}

Intestinal digesta $\mathrm{AN}$ and fecal $\mathrm{N}$ and $\mathrm{P}$ emissions were determined and are shown in Table 7. Intestinal digesta $\mathrm{AN}$ and fecal $\mathrm{N}$ and $\mathrm{P}$ emissions of piglets fed with $\mathrm{CE}$ and ANTI were not significantly different $(p>0.05)$ compared with the CON. 
Table 7. Effects of citrus extract diets, on intestinal digesta ammonia nitrogen (AN), fecal nitrogen (N) and phosphorus $(\mathrm{P})$ emissions of piglets.

\begin{tabular}{cccccc}
\hline Items & CON $^{\mathbf{1}}$ & ANTI $^{2}$ & CE $^{3}$ & SEM $^{4}$ & $p$-Value \\
\hline \multicolumn{7}{c}{ Ammonia } & nitrogen & $(\mathrm{mg} / 100 \mathrm{~g})$ \\
Ileum & 55.9 & 44.0 & 36.3 & 13.36 & 0.626 \\
Cecum & 198.7 & 209.5 & 183.2 & 23.30 & 0.725 \\
\hline \multicolumn{7}{l}{ Fecal N and P emissions (\%) } \\
N & 4.4 & 4.4 & 4.5 & 0.14 & 0.979 \\
$\mathrm{P}$ & 0.9 & 0.9 & 1.0 & 0.09 & 0.840 \\
\hline
\end{tabular}

${ }^{1}$ CON: basal diet; ${ }^{2}$ ANTI: CON $+75 \mathrm{~g} / \mathrm{t}$ chlortetracycline; ${ }^{3}$ CE: CON $+300 \mathrm{~mL} / \mathrm{t}$ citrus extract; ${ }^{4}$ SEM means standard error of the mean.

\section{Discussion}

There are many studies that have suggest that plant extracts have a positive effect on the growth performance of piglets, such as extract from Nigella sativa L. and fenugreek seed [18,19]. Naringin, for one, improves the final BW and feed conversion rate of piglets [20]. However, one study suggested that no positive effect of hesperidin on the growth performance of broilers was observed [21]. Although our results show that ANTI and CE had no statistically significant effect on animal performance, the effects of ANTI and CE were better than those of the CON group, numerically.

TP and PUN are indicators for the overall metabolism of body proteins. Within a certain range, the higher the TP concentration, the stronger the body's ability to synthesize and utilize proteins [22]. PUN concentration, on the other hand, has been negatively correlated with $\mathrm{N}$ deposition rate and protein utilization and a reduction in PUN indicates an increase in $\mathrm{N}$ utilization efficiency or a decrease in protein decomposition [23]. In this experiment, the PUN and TP concentrations in the plasma of piglets in the CE and ANTI groups were not significantly different to the CON group. PUN concentration has a close relationship with dietary crude protein concentration, but with a large enough increase of dietary crude protein intake, PUN concentration will plateau [24]. Therefore, with the crude protein of the basic diet identical among groups, the PUN concentrations did not appear to be affected by $\mathrm{CE}$ and ANTI and were within the normal range. Studies have suggested that plant extracts can promote digestion, absorption, growth and nutrient metabolism in piglets [25]. In this study, the levels of albumin, and albumin/TP in the CE group were significantly higher than those in the CON and ANTI groups, but urea nitrogen levels were not different among the groups. This implies that CE can promote protein deposition in piglets when protein metabolises while maintaining decomposition levels across treatments. Urea is the main N-containing bi-product of amino acid catabolism and has a strong linear relationship to the PUN concentration [26]. Compared with CON, piglets fed with CE had increases in urea circulating AA in the plasma and also had the highest urea content. The concentration of citrulline in the CE group increased by $30.3 \%-37.7 \%$ and the concentration of arginine increased by $18.9 \%-33.0 \%$. Both arginine and citrulline participate in the urea cycle [27], so these results imply that CE may affect the urea cycle. In support of this, it has been shown that citrus naringin can regulate proteins involved in the urea cycle pathway [28]. While this means that CE might be able to affect kidney function or citrulline uptake, there was no direct effect on urea in our study. Under normal physiological conditions, blood $\mathrm{NH}_{3}$ concentration is maintained at a low level, but damage to the liver or kidney can lead to elevated blood $\mathrm{NH}_{3}$ [29]. Our results show that blood $\mathrm{NH}_{3}$ levels were not different among the three groups, suggesting that $\mathrm{CE}$ had no negative effects on the health of the piglets, which is consistent with Ramakrishnan and Vijayakumar [28], who found that there were no significant differences between rats given naringin and control rats.

PFAA levels can reflect not only nutritional status, but also inflammatory status and disease activity. Physiologically, AA absorption and metabolism by tissues depend on the concentration of PFAA [30]. From the perspective of nutritional metabolism, AA are directly and indirectly related to the entire metabolic pathway, and the distribution of PFAA reflects the total metabolic flow of nutrients 
and their metabolites to and from all tissues and organs [31]. PFAA are a primarily source of AA used for muscle protein biosynthesis, and a key indicator of protein turnover in the body [15]. In this study, the concentrations of plasma leucine, histidine, valine, arginine, threonine, and total EAA increased when CE was administered, which indicates that their utilization in protein synthesis and/or catabolism was increased. In other words, our results suggest that CE increased the metabolic requirements for EAA. The increase in the concentrations of EAA was likely due to an increase in EAA catabolism. An alternative explanation could be that the increase in EAA concentration resulted from increased bioavailability of EAA from the diet, perhaps because CE improved the digestion of $\mathrm{N}$, and increased the availability of AA. To help approximate the fate of the excess AA, plasma 3-methylhistidine has been identified as a potential biomarker of muscle protein turnover [32]. Indeed, plasma 3-methylhistidine concentration was increased in the CE group, indicating that CE increased muscle protein synthesis or reduced protein mobilization. This is consistent with the increase of EAA in plasma of CE group. The mechanism by which CE acts is not yet clear, and further study is needed. In summary, the fact that increases in AA concentrations were mainly observed in CE group may indicates that CE is more beneficial to piglets than antibiotics.

$\mathrm{VH}, \mathrm{CD}$, and VCR are key indicators of the status of the intestinal barrier and are closely related to nutrient digestion and absorption. Increased villus diameter and VCR are indicative of a higher number of more functionally mature intestinal epithelial cells [33]. Increasing the VH and VCR can improve the intestinal absorption capacity, while a decrease of CD reflects an increase in the proliferation of intestinal epithelial cells [34]. Many studies have suggested that plant extract can promote intestinal development and improve intestinal morphology in animals. For example, feeding grape seed grape residue extract significantly increased the duodenal VCR in piglets [35]. In another example, compared with lipopolysaccharide-stimulated mice, Acanthopanax senticosus extract increased the VH and VCR of jejunum and ileum, and decreased jejunum CD [34]. Likewise, Lagenaria siceraria extract increased the height, width and area of jejunal villi in irradiated mice, and improved villi morphology and tight junction integrity [36]. In the present study, the VH (duodenum) and VCR (duodenum, ileum) of the CE and ANTI groups were higher than that of CON, while the CD (duodenum, jejunum, ileum) was lower, which is consistent with previous studies [34-36]. These measurements demonstrate the anti-inflammatory and anti-oxidant effects of CE flavonoids on intestinal repair and protection, and the overall improvement of intestinal morphology. Flavonoids are involved in the maintenance of the integrity of the intestinal tight junction barrier, which helps ensure the health of piglets [37]. Naringin supplementation, for example, was able to inhibit colonic inflammation and injury induced by sodium dextran sulfate, protecting the intestinal barrier in mice [38]. Likewise, citrus peel flavonoids increased the expression of the proteins Claudin- 4 and Occludin in the ethanol-induced Caco-2 monolayer [37].

Maintaining normal intestinal digestion and absorption functions is important in preventing weaning stress. The digestion of proteins, fats, and carbohydrates can be achieved by proteases, lipases, and amylases. For example, enzymes such as sucrase, glucanase, lactase, and amylase and maltase in the intestinal mucosa are involved in sugar catabolism and affect the digestion and absorption of carbohydrates [39]. In this experiment, there was no change in the activities of sucrose, maltase, and amylase in duodenum and jejunum when CE and ANTI were administered. This suggests that CE and ANTI do not affect the digestion and absorption of carbohydrates. In addition, these results show that dietary supplementation with CE increased the activities of AKP, lipase, and trypsin in the duodenum and jejunum of piglets. Intestinal AKP is considered to be a key marker enzyme and plays an important role in the intestinal absorption of lipids [40], and lipase is responsible for the digestion of lipids [41]. These results again support the hypothesis that CE improves the digestion and absorption of fat and protein in piglets. At the same time, the observed improvement of intestinal digestion by $\mathrm{CE}$ supplementation was consistent with the improvements observed in the morphological comparison.

$\mathrm{N}$ emissions from pig excreta are $\mathrm{NH}_{3}$, ammonium ions and urea (with traces of nitrate and nitrite) [42]. $\mathrm{NH}_{3}$ and amines are thought to be harmful to intestinal health. These compounds, when in high concentrations in the intestine, can negatively affect the development of intestinal mucosa [43], 
which may be the cause of diarrhea in weaned piglets. CE reduced the AN concentration in the ileum and cecum digesta $(7.8 \%-35.0 \%)$. This is may be caused by the extracts' flavonoid compounds, an increase in $\mathrm{N}$ digestibility (enhancement of trypsin activity), or changes in microbial flora. Although the data are not statistically significant, it can still be used to guide animal production, and is worth investigating further.

In pig production, inefficient feed digestion can result in increased nutrient emissions into the environment. The nutrients of greatest environmental concern are $\mathrm{N}$ and $\mathrm{P}$, which are usually supplied in excess in the diet [44]. Our study found that CE did not to reduce $\mathrm{N}$ and $\mathrm{P}$ emissions from feces, which is consistent with Panetta et al. [45], who observed no significant difference in AN content and $\mathrm{N}$ emission rate in feces when fed with Yucca extract. Similarly, Yucca extract did not reduce the concentration of total N, AN, P, or total ammonia in horse manure [46]. Reducing nitrogen and phosphorus emissions from feces is not a simple matter and more research is needed.

\section{Conclusions}

In brief, CE increased the absorption and utilization of N nutrients, improved intestinal morphology, and improved digestive enzymes activity, but had no effect on fecal $\mathrm{N}$ and $\mathrm{P}$ emissions. $\mathrm{CE}$ and antibiotics have similar effects in these aspects.

Author Contributions: Conceptualization, Y.C. and X.M.; Data curation, Y.C.; Formal analysis, Y.C. and Z.T.; Methodology, Z.T.; Funding acquisition, G.W. and X.M.; Project administration, G.W.; Supervision, W.C.; Writing-original draft, Y.C.; Writing — review and editing, Y.C. and X.M. All authors have read and agreed to the published version of the manuscript.

Funding: This research was funded by Guangdong Provincial Special Fund for Modern Agriculture Industry Technology Innovation Teams (2019KJ115), Guangzhou Municipal Science and Technology Project (201707020007) and Talent Project of the Guangdong Academy of Agricultural Sciences (201803).

Conflicts of Interest: The authors declare no conflict of interest.

\section{References}

1. Campbell, J.M.; Crenshaw, J.D.; Polo, J. The biological stress of early weaned piglets. J. Anim. Sci. Biotechnol. 2013, 4, 19. [CrossRef] [PubMed]

2. Ferket, P.; van Heugten, E.; Van Kempen, T.; Angel, C. Nutritional strategies to reduce environmental emissions from non-ruminants. Phys. Rev. B Condens. Matter 2002, 36, 3413-3421.

3. Pantsulaia, I.; Iobadze, M.; Pantsulaia, N.; Chikovani, T. The effect of citrus peel extracts on cytokines levels and T regulatory cells in acute liver injury. Biomed. Res. Int. 2014, 2014, 127879. [CrossRef] [PubMed]

4. Lee, Y.R.; Jung, J.H.; Kim, H.S. Hesperidin partially restores impaired immune and nutritional function in irradiated mice. J. Med. Food 2011, 14, 475-482. [CrossRef] [PubMed]

5. Kim, A.; Im, M.; Gu, M.J.; Ma, J.Y. Citrus unshiu peel extract alleviates cancer-induced weight loss in mice bearing CT-26 adenocarcinoma. Sci. Rep. 2016, 6, 24214. [CrossRef]

6. Toscano-Garibay, J.D.; Arriaga-Alba, M.; Sanchez-Navarrete, J.; Mendoza-Garcia, M.; Flores-Estrada, J.J.; Moreno-Eutimio, M.A.; Espinosa-Aguirre, J.J.; Gonzalez-Avila, M.; Ruiz-Perez, N.J. Antimutagenic and antioxidant activity of the essential oils of Citrus sinensis and Citrus latifolia. Sci. Rep. 2017, 7, 11479. [CrossRef]

7. Ndayishimiye, J.; Lim, D.J.; Chun, B.S. Antioxidant and antimicrobial activity of oils obtained from a mixture of citrus by-products using a modified supercritical carbon dioxide. J. Ind. Eng. Chem. 2018, 57, 339-348. [CrossRef]

8. Smeriglio, A.; Cornara, L.; Denaro, M.; Barreca, D.; Burlando, B.; Xiao, J.; Trombetta, D. Antioxidant and cytoprotective activities of an ancient Mediterranean citrus (Citrus lumia Risso) albedo extract: Microscopic observations and polyphenol characterization. Food Chem. 2019, 279, 347-355. [CrossRef]

9. Goliomytis, M.; Simitzis, P.; Papalexi, A.; Veneti, N.; Hager-Theodorides, A.L.; Charismiadou, M.A.; Deligeorgis, S.G. Influence of citrus flavonoids on laying hen performance, inflammatory immune response, egg quality and yolk oxidative stability. Br. Poult. Sci. 2019, 60, 272-278. [CrossRef] 
10. Zanotti, S.D.G.; de Abreu, R.L.; Zeppone, C.I.; Borges, C.T. Orange juice and hesperidin promote differential innate immune response in macrophages ex vivo. Int. J. Vitam. Nutr. Res. 2013, 83, 162-167. [CrossRef]

11. Wang, J.; Qi, Y.; Niu, X.; Tang, H.; Meydani, S.N.; Wu, D. Dietary naringenin supplementation attenuates experimental autoimmune encephalomyelitis by modulating autoimmune inflammatory responses in mice. J. Nutr. Biochem. 2018, 54, 130-139. [CrossRef] [PubMed]

12. Pourhossein, Z.; Qotbi, A.A.; Seidavi, A.; Laudadio, V.; Centoducati, G.; Tufarelli, V. Effect of different levels of dietary sweet orange (Citrus sinensis) peel extract on humoral immune system responses in broiler chickens. Anim. Sci. J. 2015, 86, 105-110. [CrossRef] [PubMed]

13. Simitzis, P.E.; Charismiadou, M.A.; Goliomytis, M.; Charalambous, A.; Ntetska, I.; Giamouri, E.; Deligeorgis, S.G. Antioxidant status, meat oxidative stability and quality characteristics of lambs fed with hesperidin, naringin or $\alpha$-tocopheryl acetate supplemented diets: Antioxidant status, meat oxidative stability and quality characteristics of lambs fed with hesperid. J. Sci. Food Agric. 2018, 99, 343-349. [CrossRef] [PubMed]

14. Cui, Y.Y.; Tian, Z.M.; Deng, D.; Wang, G.; Lu, H.J.; Chen, W.D.; Ma, X.Y. Effects of citrus extract on immunity of piglets. Chin. J. Anim. Nutr. 2019. Available online: http://kns.cnki.net/kcms/detail/11.5461.s.20191213. 1421.108.html (accessed on 12 December 2019). [CrossRef]

15. Obled, C. Amino acid requirements in inflammatory states. Can. Vet. J. 2003, 83, 365-373. [CrossRef]

16. Ren, M.; Zhang, S.H.; Zeng, X.F.; Liu, H.; Qiao, S.Y. Branched-chain amino acids are beneficial to maintain growth performance and intestinal immune-related function in weaned piglets fed protein restricted diet. Asian Australas. J. Anim. Sci. 2015, 28, 1742-1750. [CrossRef]

17. Pu, W.X.; Wei, Y.X.; Meng, X.Q.; Wang, L.; Chen, J.; Yang, Z.Q. Determination of NH4+-N content in castrointestinal with indophenol blue spectrophotometric method. J. Gansu Agric. Univ. 2008, 5, $13-17$.

18. Petrujkic, B.T.; Beier, R.C.; He, H.; Genovese, K.J.; Swaggerty, C.L.; Hume, M.E.; Crippen, T.L.; Harvey, R.B.; Anderson, R.C.; Nisbet, D.J. Nigella sativa L. as an alternative antibiotic feed supplement and effect on growth performance in weanling pigs. J. Sci. Food Agric. 2017, 98, 3175-3181.

19. Begum, M.; Hossain, M.M.; Kim, I.H. Effects of fenugreek seed extract supplementation on growth performance, nutrient digestibility, diarrhoea scores, blood profiles, faecal microflora and faecal noxious gas emission in weanling piglets. J. Anim. Physiol. Anim. Nutr. 2016, 100, 1121-1129. [CrossRef]

20. Goodarzi, B.F.; Manner, K.; Zentek, J. The impacts of Macleaya cordata extract and naringin inclusion in post-weaning piglet diets on performance, nutrient digestibility and intestinal histomorphology. Arch. Anim. Nutr. 2018, 72, 178-189. [CrossRef]

21. Chen, P.; Yang, Z.B.; Huang, L.B.; Ding, X.; Jiang, S.Z. Effects of Illicium verum and Eucommia Leaf extracts on growth performance, serum enzyme activities and distribution and expression of tumor necrosis factor $\alpha$ in liver of weaned piglets. Chin. J. Anim. Nutr. 2017, 29, 874-881.

22. Cheng, S.S.; Li, Y.; Geng, S.J.; Hu, L.S.; Fu, X.F.; Han, X.Y. Effects of dietary fresh fermented soybean meal on growth performance, ammonia and particulate matter emissions, and nitrogen excretion in nursery piglets. J. Zhejiang Univ. Sci. B 2017, 18, 1083-1092. [CrossRef] [PubMed]

23. Jayaraman, B.; Htoo, J.; Nyachoti, C.M. Effects of dietary threonine: Lysine ratioes and sanitary conditions on performance, plasma urea nitrogen, plasma-free threonine and lysine of weaned pigs. Anim. Nutr. 2015, 1, 283-288. [CrossRef] [PubMed]

24. Lan, R.; Tran, H.; Kim, I. Effects of probiotic supplementation in different nutrient density diets on growth performance, nutrient digestibility, blood profiles, fecal microflora and noxious gas emission in weaning pig. J. Sci. Food Agric. 2017, 97, 1335-1341. [CrossRef] [PubMed]

25. Omodanisi, E.I.; Aboua, Y.G.; Oguntibeju, O.O. Assessment of the anti-hyperglycaemic, anti-inflammatory and antioxidant activities of the methanol extract of Moringa Oleifera in diabetes-induced nephrotoxic male wistar rats. Molecules 2017, 22, 439. [CrossRef] [PubMed]

26. Lan, R.; Li, T.; Kim, I. Effects of xylanase supplementation on growth performance, nutrient digestibility, blood parameters, fecal microbiota, fecal score and fecal noxious gas emission of weaning pigs fed corn-soybean meal-based diet. Anim. Sci. J. 2017, 88, 1398-1405. [CrossRef]

27. Cai, Y.; Zimmerman, D.R. Relationship of plasma urea nitrogen and urea-cycle amino acid concentrations in swine to dietary electrolyte balance and water intake. Nutr. Res. 1995, 15, 1517-1524. [CrossRef]

28. Ramakrishnan, A.; Vijayakumar, N. Urea cycle pathway targeted therapeutic action of naringin against ammonium chloride induced hyperammonemic rats. Biomed. Pharm. 2017, 94, 1028-1037. [CrossRef] 
29. Weiner, I.D. Roles of renal ammonia metabolism other than in acid-base homeostasis. Pediatr. Nephrol. 2017, 32, 933-942. [CrossRef]

30. Cynober, L.A. Plasma amino acid levels with a note on membrane transport: Characteristics, regulation, and metabolic significance. Nutrition 2002, 18, 761-766. [CrossRef]

31. Liao, S.F.; Wang, T.; Regmi, N. Lysine nutrition in swine and the related monogastric animals: Muscle protein biosynthesis and beyond. Springerplus 2015, 4, 147. [CrossRef] [PubMed]

32. Kochlik, B.; Gerbracht, C.; Grune, T.; Weber, D. The influence of dietary habits and meat consumption on plasma 3-methylhistidine-A potential marker for muscle protein turnover. Mol. Nutr. Food Res. 2018, 62, e1701062. [CrossRef] [PubMed]

33. Tucci, F.M.; Thomaz, M.C.; Nakaghi, L.S.O.; Hannas, M.I.; Scandolera, A.J.; Budiño, F.E.L. The effect of the addition of trofic agents in weaned piglet diets over the structure and ultra-structure of small intestine and over performance. Arquivo Brasileiro De Medicina Veterinária E Zootecnia 2011, 63, 931-940. [CrossRef]

34. Han, J.; Liu, L.; Yu, N.; Chen, J.; Liu, B.; Yang, D.; Shen, G. Polysaccharides from Acanthopanax senticosus enhances intestinal integrity through inhibiting TLR4/NF- $\kappa B$ signaling pathways in lipopolysaccharide-challenged mice. Anim. Sci. J. 2015, 87, 1011-1018. [CrossRef]

35. Gessner, D.K.; Fiesel, A.; Most, E.; Dinges, J.; Wen, G.; Ringseis, R.; Eder, K. Supplementation of a grape seed and grape marc meal extract decreases activities of the oxidative stress-responsive transcription factors NF-kB and Nrf2 in the duodenal mucosa of pigs. Acta. Vet. Scand. 2013, 55, 18. [CrossRef]

36. Sharma, D.; Goel, H.C.; Chauhan, S. Radioprotective potential of Lagenaria siceraria extract against radiation-induced gastrointestinal injury. Appl. Physiol. Nutr. Metab. 2016, 41, 1248-1254. [CrossRef]

37. Chen, X.M.; Kitts, D.D. Flavonoid composition of orange peel extract ameliorates alcohol-induced tight junction dysfunction in Caco-2 monolayer. Food Chem. Toxicol. 2017, 105, 398-406. [CrossRef]

38. Azuma, T.; Shigeshiro, M.; Kodama, M.; Tanabe, S.; Suzuki, T. Supplemental naringenin prevents intestinal barrier defects and inflammation in colitic mice. J. Nutr. 2013, 143, 827-834. [CrossRef]

39. Courtois, P.; Meuris, S.; Sener, A.; Malaisse, W.J.; Scott, F.W. Invertase, maltase, lactase, and peroxidase activities in duodenum of BB rats. Endocrine 2002, 19, 293-300. [CrossRef]

40. Ejaz, S.A.; Saeed, A.; Siddique, M.N.; Nisa, Z.U.; Khan, S.; Lecka, J.; Sévigny, J.; Iqbal, J. Synthesis, characterization and biological evaluation of novel chalcone sulfonamide hybrids as potent intestinal alkaline phosphatase inhibitors. Bioorg. Chem. 2017, 70, 229-236. [CrossRef]

41. Pirahanchi, Y.; Sharma, S. Biochemistry, Lipase. 2019. Available online: https://www.ncbi.nlm.nih.gov/books/ NBK537346/ (accessed on 8 October 2019).

42. Powers, W.; Capelari, M. Production, management and the environment symposium measurement and mitigation of reactive nitrogen species from swine and poultry production. J. Anim. Sci. 2017, 95, 2236-2240. [CrossRef] [PubMed]

43. Jha, R.; Leterme, P. Feed ingredients differing in fermentable fibre and indigestible protein content affect fermentation metabolites and faecal nitrogen excretion in growing pigs. Animal 2012, 6, 603-611. [CrossRef] [PubMed]

44. Zhang, X.; Li, Z.; Yang, H.; Liu, D.; Cai, G.; Li, G.; Mo, J.; Wang, D.; Zhong, C.; Wang, H.; et al. Novel transgenic pigs with enhanced growth and reduced environmental impact. Elife 2018, 7, e34286. [CrossRef] [PubMed]

45. Panetta, D.M.; Powers, W.J.; Xin, H.; Kerr, B.J.; Stalder, K.J. Nitrogen excretion and ammonia emissions from pigs fed modified diets. J. Environ. Qual. 2006, 35, 1297-1308. [CrossRef]

46. Gordon, M.E.; Edwards, M.S.; Sweeney, C.R.; Jerina, M.L. Effects of added chelated trace minerals, organic selenium, yeast culture, direct-fed microbials, and Yucca schidigera extract in horses: II. Nutrient excretion and potential environmental impact. J. Anim. Sci. 2013, 91, 3909-3916. [CrossRef]

(C) 2020 by the authors. Licensee MDPI, Basel, Switzerland. This article is an open access article distributed under the terms and conditions of the Creative Commons Attribution (CC BY) license (http://creativecommons.org/licenses/by/4.0/). 